\title{
FLIGHT INSURANCE AND FEDERAL TAXATION: A CRITICAL EXAMI- NATION OF THE NOEL CASE
}

John D. Johnston, JR.*

$T$ HOUGHTFUL observers have long recognized, and generally accepted, the fact that the Anglo-American tradition of judicial review often forces judges to assume a policy-making role. This function results, in part, from the conviction that older precedents should be periodically re-evaluated in the contemporary context. In certain areas, however, the primary policy-making responsibility rests with the legislature. Taxation is an example; discussion of a tax problem should proceed from the pertinent revenue act itself.

Statutory construction is eminently a judicial function, to be sure. But existing authority may be entitled to considerable judicial deference. Such authority may consist, for example, of an administrative interpretation that has received judicial approval over a period of sufficient length to justify an inference of legislative acquiescence. Summary rejection of this type of authority may produce an unsound result. An example, in the writer's opinion, is In re Noel's Estate. ${ }^{1}$

\section{INTRODUCTION}

On the evening of June 19, 1956, Marshall Noel and his wife drove from their home in New Jersey to Idlewild Airport, where Noel purchased a round trip ticket to Caracas, Venezuela. He then applied for two policies of air travel accident insurance ${ }^{2}$ with death

* Assistant Professor of Law and Assistant Dean, Duke University School of Law; Editor, Journal of Legal Enucation. This article was suggested by the author's colleague, Professor Charles L. B. Lowndes, whose invaluable assistance in its preparation is gratefully acknowledged.

1332 F.2d 950 (3d Cix.), cert. granted sub nom. Commissioner v. Estate of Nocl, 379 U.S. 927 (1964) (No. 503).

2 One policy was issued by The Fidelity and Casualty Co. of New York, the other by Continental Casualty $\mathrm{Co}$. Both were sold and countersigued by an employee of Airport Sales Corp., the authorized selling agent for each insurer.

The Fidehity application was so worded that only the insured could apply for 
benefits in the amount of 125,000 dollars, naming his wife the beneficiary of the accidental death benefit provisions of each policy. After completing the applications, Noel handed them to the sales clerk; the five dollars in premiums was paid by his wife. When the clerk had countersigned the policies, Noel instructed him to hand the policies to Mrs. Noel, who retained them in her custody. Each policy contained provisions reserving to the insured the right to assign or surrender the policy and to change the beneficiary. ${ }^{3}$ Some three hours after take-off Noel's plane crashed into the Atlantic Ocean, leaving no survivors. In due course his widow made claim for the accidental death benefits of the air travel insurance policies and received the proceeds. When the estate tax return was filed by Noel's executors, the flight insurance proceeds were not included in his gross estate. The Commissioner determined a deficiency, and the case was heard by the Tax Court. ${ }^{4}$

The estate advanced two contentions: first, that the proceeds of air travel insurance are not "insurance under policies on the life of the decedent" under section 2042 (2) of the Internal Revenue Code; 5 and second, that even if such proceeds are "life insurance," they should not be taxed to the decedent's estate because at the time of his death he retained no incidents of ownership in the policies. Both contentions were rejected by the Tax Court. Relying on a 1929 decision of the Board of Tax Appeals, ${ }^{6}$ in which accidental

coverage. The Continental application could be signed by someone other than the insured, provided the insured gave his consent in writing. Brief for PetitionersAppellants, p. 3.

"Each policy contained the following clause: "CHANGE OF BENEFICIARY: The right to change of beneficiary is reserved to the insured and the consent of the beneficiary or beneficiaries shall not be requisite to surrender or assignment of this policy or to any change of beneficiary or beneficiaries, or to any other changes in this policy." Estate of Marshall Noel, 39 T.C. 466, 469 (1963).

Ibid.

${ }^{8}$ INT. REv. CODE of 1954, $\$ 2042$ provides in part as follows: "SEC. 2042. PROCEEDS OF LIFE INSURANCE.

"The value of the gross estate shall include the value of all property-

"(1) Recervable BY THE EXecuTor.-To the extent of the amount receivable by the executor as insurance under policies on the life of the decedent.

“(2) RECEIVABLE BY OTHER BENEFICIARIES,-To the extent of the amount receivable by all other beneficiaries as insurance under policies on the life of the decedent with respect to which the decedent possessed at his death any of the incidents of ownership, exercisable either alone or in conjunction with any other person. For purposes of the preceding sentence, the term 'incident of ownership' includes a reversionary interest (whether arising by the express terms of the policy or other instrument or by operation of law) only if the value of such reversionary interest exceeded 5 percent of the value of the policy immediately before the death of the decedent. ..."

- Leopold Ackerman, 15 B.T.A. 635 (1929). 
death benefits of several life and accident insurance policies had been held includible in the decedent's estate under a comparable provision of the Revenue Act of 1924, ${ }^{7}$ the court stated that

the matter has been settled for too long a period to warrant reexamination. The statutory provisions involved are substantially identical as they relate to this question. We follow Ackerman here. ${ }^{8}$

The court further held that the decedent's reserved right to change the beneficiary was an incident of ownership in the policy, rendering the proceeds includible in his estate ${ }^{\vartheta}$ irrespective of the practical difficulties in actually changing the beneficiary. ${ }^{10}$ Finally, the court found that the evidence presented was insufficient to establish an oral assignment of the policies to Mrs. Noel.11

The executors appealed to the Court of Appeals for the Third Circuit, reiterating both contentions. The Commissioner insisted that flight insurance proceeds are includible under section 2042 (2).

\footnotetext{
"Revenue Act of 1924, ch. 234, .8 902 (g), 43 Stat. 305.

839 T.C. at 470 .

${ }^{\circ}$ It has been uniformly held that the right to change the beneficiary is an incident of ownership in a life insurance policy. See Lowndes \& KRAMMER, Federar EsTate AND GIFT TAXES 280 n.34 (2d ed. 1962).

${ }^{10}$ Once he has boarded the plane, a passenger would find it extremely difficult to effect a change of heneficiary. The Tax Court relied on the fact that Noel had purchased coverage for a round trip, "and in the normal course the right to change the beneficiary would have been meaningful prior to commencement of the return trip." 39 T.C. at 472.

This reasoning would not appear to apply to coverage for a one-way trip. The crucial question is this: does a right or power cease to be an "incident of owner. ship" when its possessor is unable to exercise it? The Code is, perhaps, equivocal. Section 2042 (2) refers to incidents of ownership possessed by the decedent, exercisable either alone or in conjunction with another person. See note 5 supra. Whether this imposes a dual requirement of possession plus exercisability, or whether the "exercisable" clause merely serves to specify that powers possessed jointly by the insured and other persons will result in taxation of life insurance proceeds, has not been decided by the Supreme Court. The Treasury takes the latter view, however, and has been upheld in the Tax Court and several courts of appeal. See Estate of John J. Round, 40 T.C. 970 (1963); Estate of Virginia H. West, 9 T.C. 736 (1947), aff'd, I73 F.2d 505 (8th Cir. 1949); Estate of Edward L. Furd, 6 T.C. 819 (1946), afjd, 160 F.2d 610 (Ist Cir. 1947); Rev. Rul. 123, 1961-62 CuM. BuLI. I51.

11 The court thus avoided a choice of law problem: oral assignments of insurance are valid in New Jersey, hut more doubtful in New York. Compare Metropolitan Life Ins. Co. v. Woolf, 138 N.J.Eq. 450, 47 A.2d 340 (1946), with McNamee v. Griffin, 137 N.Y.S.2d 749 (App. Div.), aff'd, 309 N.Y. 864, 131 N.E.2d 284 (1955) and Katzman v. Aetna Life Ins. Co., 309 N.Y. 197, 128 N.E.2d 307 (1955).

If an assignment is valid and divests the insured of all incidents of ownership, no tax is incurred under $\S 2042$ (2). If death occurs within three years of the transfor, however, the proceeds may be taxable under $\S 2035$ as a transfer in contemplation of death. Lowndes \& KRAMER, op. cit. supra note 9, at 286-87. See text accompanying notes 104-05 infra.
} 
He further contended that if the court should find a valid assignment of the policies to Mrs. Noel, the proceeds were taxable under section 2035 as a transfer in contemplation of death. ${ }^{12}$ The Third Circuit reversed the Tax Court, holding in favor of the estate on the ground that air travel accident insurance proceeds are not "insurance under policies on the life of the decedent" under section 2042 (2). The reasoning of Ackerman was expressly rejected. ${ }^{13}$

The Noel case represents a major interpretation of section 2042 affecting millions of air travel accident insurance policyholders. ${ }^{\mathbf{1 4}}$ Moreover, the Third Circuit's rationale is broad enough to cast doubt on the taxability of other forms of accidental death insurance. ${ }^{15}$ An understanding of the issues presented requires an examination of insurance concepts as well as the history, purpose and proper construction of section 2042.

\section{II \\ The "Distinction" Between Life and ACCIDENT INSURANCE}

A. The Opinion

Although the title of section 2042 is "Proceeds of Life Insurance," the term "life insurance" does not appear in the statute itself. Instead, the term "policies on the life of the decedent" is used.16 It seems clear that the latter terminology is susceptible to a broader interpretation than the former, and that under settled rules of statutory construction the wording of the statute itself, rather than the

\footnotetext{
${ }^{12}$ Brief for Respondent, Pp. 15-16. See note 11 supra.

13332 F.2d at 952.

14 The president of the corporation acting as selling agent for the companies issuing the two Noel policies testified that between seven and eight million such policies are sold annually. Brief for Petitioners-Appellants, p. 16a. Fortunately, air travel has become considerably safer during the past three decades. In 1957-59, the passenger death rate for scheduled airliners was approximately one-third the rate of automobile travel on turnpikes. Metropolitan Life INs. Co., Statistical Bull., Aug. 1960 , p. 10 .

The insurance payout for air disasters, however, is very high. For instance, a total of 18.6 million dollars was paid by life and casualty insurers to beneficiaries of victims of four air crashes in 1962. Included in this figure is 8.8 million dollars in "travel accident insurance death payments." INSTITUTE OF LIFE INS., LIFE INSURANCE FAcT Book 42 (1963).

${ }^{15}$ For example, term policies (accident policies written for a specific term of years, rather than for a single trip) and accidental death benefit provisions of life insurance contracts (the so-called "double indemnity" clause). Accidental death benefits "paid under double indemnity and similar protection" totalled 73 million dollars in 1962. INSTrTUTE OF LIFE INS., LIFE INSURANCE FACT BOoK 39-42 (1963).

${ }^{10}$ See note 5 supra.
} 
title, should control.17 The Third Circuit proceeded as though "life insurance" were the critical term, and the result reached in the case was made to depend upon whether the policies in question could be characterized as "life insurance" or "accident insurance."

Having reduced the controversy to these terms, the opinion proceeded to consider the distinction between the two types of insurance. Life insurance was found to be payable

upon the occurrence of an inevitable event. The contingency insured against is the death of the insured regardless of its cause unless, of course, the cause is one excepted under the policy. . . . Life insurance has several economic and investment features not common to accident insurance. Upon issuance of the policy the insurer assumes an absolute risk of loss and the insured acquires an immediate estate which by the terms of the policy is transferable on his death. ${ }^{18}$

Accident policies, on the other hand, were found to be payable

- for any loss sustained by reason of an event which is evitable and not likely to occur. The contingency insured against is the accident, death being only one of several liability creating consequences. ... Upon issuance of the policy the insurer assumes a conditional risk of loss and the insured, as well as the beneficiary, acquire nothing more than an inchoate arid defeasible right.10

The distinction which the court drew is defective in several respects. First, not all policies of life insurance have "economic and investment features not common to accident insurance." Term life insurance policies contain no investment features; ${ }^{20}$ neither do accidental death benefit, or "double indemnity," provisions of ordinary life insurance policies. ${ }^{21}$ Secondly, it is not true that upon issuance of life insurance policies the insurer "assumes an absolute risk of loss." Death by certain causes may be excluded from coverage, and the insurer may avoid liability in cases where the insured is guilty of breach of warranty, misrepresentation or concealment in procuring issuance of the policy. Moreover, under a term life insurance policy risk of loss is conditioned upon death within the term of the policy.

22 "It is elementary that the meaning of a statute must, in the first instance, be sought in the language in which the act is framed .... [T] he name given to an act by way of designation or description ... cannot change the plain import of its words." Caminetti v. United States, 242 U.S. 470, 485, 490 (1916). See also Crooks v. Harrelson, 282 U.S. 55 (1930).

18332 F.2d at 952 .

${ }^{10}$ Id. at 952.53 .

20 See RIegel \& Loman, Insurance 56 (1921).

${ }^{21}$ See generally KNIGHT, AdvaNced LIFE INSURANce $254-59$ (1926). 
The insured simply buys protection during the period of the term, and the insurer incurs liability only if death occurs within the stated term. ${ }^{22}$ The policy coverage can terminate in a number of ways, including non-renewal ${ }^{23}$ (and termination of employment under employee group insurance plans paid for by the employer). ${ }^{24}$

Perhaps the crux of the distinction drawn by the Third Circuit between life and accident insurance is its view of the operative contingencies that determine the insurer's liability. In life insurance, the contingency insured against was stated to be "the death of the insured regardless of its cause unless, of course, the cause is one excepted under the policy." 25 On the other hand, in accident insurance the contingency insured against was found to be "the accident, death being only one of several liability creating consequences." ${ }^{28}$ This distinction is spurious, since more than a mere accident is required before the insurer becomes liable under an accident insurance policy. If an accident occurs, but the insured is not injured, no liability is incurred. Liability is conditioned upon an accident plus an additional contingency resulting from it. If the other contingency is non-fatal injury to the insured, the disability provisions of the policy become effective. ${ }^{27}$ If the additional factor is death of the insured, then the face amount of the policy is payable to the stated beneficiary. The death of the insured, far from being "only one of several liability creating consequences," is as much a prerequisite for liability under a death benefit provision as

22 "A term policy is one under which the sum insured becomes payable provided the person insured dies within a stated period. . . . It covers a contingency only and not a certainty, as do other kinds of policies." Maclean, Life Insurance 48 (5th ed. 1989).

${ }^{2 a}$ Normally, the premiums increase as the insured's age advances. Thus the insured who is in good health has little incentive to renew his coverage. "[T] to be a strong selection exercised against the company at the time of renewal, and this selection will be increasingly great as the age and the renewal premium increase. The temptation to drop a policy which calls for increasingly greater premiums will cause many of those who remain in good health to fail to renew at the time a premium increase takes effect. On the other hand, the majority of those who are in poor health will almost certainly take advantage of the right of renewal, with the result that as time goes on the mortality experience among the surviving policyholders will be increasingly unfavorable." MACLEAN, op. cit. supra note 22, at 53.

24 Crawford \& Hardan, Group Insurance \$ 92 (1936); Gregc, Group Life INSURance $32-33$ (rev, ed. 1957); ILSE, Group Insurance and EMPLoyee Retirement Plans 93 (1953).

25 332 F.2d at 952.

20 Ibid.

${ }^{27}$ Each policy provided for payment to the insured of specific amounts for certain bodily injuries sustained as a result of an air crash. 39 T.C. at 468 . 
the accident itself. Neither contingency is independent. Both must occur in sequence: first the accident, then the resulting death.

\section{B. Other Arguments}

The executors relied upon several other alleged distinctions between life and accident insurance which were not mentioned in the opinion. For instance, the companies which issued the policies to Noel were not authorized to issue life insurance; ${ }^{28}$ they were licensed casualty insurers. A state regulatory distinction sbould not, of course, be incorporated into an Internal Revenue Code provision without some evidence that Congress so intended. ${ }^{20}$ Since no such evidence was presented with regard to this distinction and section 2042 (2), the court properly refused to consider this argument.

In support of their contention that life and accident insurance cover different risks, the executors argued that in the case of life insurance the age, health, occupation and moral character of the insured are relevant, whereas such factors are not taken into consideration in issuing flight insurance. ${ }^{30}$ Two observations may be made which appear to controvert this contention. First, most group life insurance policies require no formal application, physical examination or assessment of moral character by the insurer. ${ }^{31}$ Under many group plans the premium is not variable according to the age of the insured. ${ }^{32}$ Secondly, while age, health and occupation of the insured are not relevant in issuing flight insurance (where no insured has control over the plane) or group accident and health policies paid for by employers, these factors are relevant in the issuance of individual health and accident policies. ${ }^{83}$

\footnotetext{
${ }^{28}$ Brief for Petitioners-Appellants, pp. 6, 17a.

20 See, e.g., Lyeth v. Hoey, 305 U.S. 188 (1938); United States v. Kintner, 216 F.2d 418 (9th Gir. 1954).

${ }^{80}$ Brief for Petitioners-Appellants, pp. 6, 18a. For a discussion of the relevance of these factors to the estate tax definition of "insurance," see text accompanying notes $80-84$ infra.

${ }^{31}$ See Estate of Keller v. Commissioner, 312 U.S. 543, 545 (1941).

s2 The premium is, of course, determined by reference to the "average age" of the group. Employee contributions are on the basis of a "flat rate," however. Grecc, op. cit. supra note 24, at 182-83. See generally $i d$. ch. VII. Sce also ILSE, op. cit. supra note 24 , chs. $4-5$.

The New York Stock Exchange gratuity fund, held to be "life insurance" in Commissioner v. Treganowan, 183 F.2d 288 (2d Cir. 1950), was a level-premium assessment unrelated to age, health or living habits of exchange members. Sec text accompanying notes $80-84$ infra.

${ }^{8}$ See Miller, Rates and Reserves-Personal Commercial and Noncancellable Contracts, in ACcident AND SickNess INSURANce 184-91 (McCahan ed, 1954).
} 
Perhaps the most amazing contention raised by the executors was that policies of flight insurance, unlike life insurance, are "not used in estate planning." ${ }^{34}$ In the Tax Court the president of the sales agency for the two Noel policies was permitted so to testify. ${ }^{35}$ This extraordinary testimony was rebutted, however, by the widow of the insured, who testified that "he [Noel] was doing an awful lot of air traveling and I was a little worried about it and if anything happened, $\mathrm{we}^{36}$ would be protected." ${ }^{37}$

\section{The Supporting Authority}

The unsoundness of the Third Circuit's conclusion that section 2042 incorporates a distinction between accident insurance and life insurance is further revealed by the four cases cited in support of its reasoning.

In the first case, Bowles v. Mutual Ben. Health d Acc. Ass'n, , $^{38}$ an applicant for health and accident insurance represented that he had no other health and accident insurance then in force. In fact, he had previously submitted an application for a life insurance policy with an accidental death benefits clause. After the issuance of the accident policy the insured suffered accidental eye injuries. In seeking to avoid liability under its contract, the accident insurer contended that the insured had breached a provision requiring him to notify it if he took out "additional insurance." ${ }^{39}$ The court held that this clause imposed a duty on the insured to notify the insurer if he took out additional accident or health insurance. It then proceeded to consider the question whether the accidental death benefits provision of the life insurance policy subsequently issued to the insured constituted coverage of the type which the insured

\footnotetext{
84 Brief for Petitioners-Appellants, p. 6.

${ }^{85} \mathrm{Id}$, at p. 18a.

so An apparent reference to herself and the couple's three daughters.

${ }^{87}$ Brief for Petitioners-Appellants, p. 22a.

${ }^{3 s} 99$ F.2d 44 (4th Cir. 1938).

so The following question had apparently been answered in the affirmative by the insured:

"18. Do you hereby apply to the Mutual Benefit Health \& Accident Association for a policy to be based upon the foregoing statements of facts, and do you understand and agree that the falsity of any statement in this application shall bar the right to recover if such false statement is made with intent to deceive or materially affects either the acceptance of the risk or the hazard assumed by the Association, and do you agree to notify the Association promptly of any change in your occupation, or if you take additional insurance, and do you hereby authorize any physician or other person who bas intended [sic] or may attend you to disclose any information thus acquired?" Id. at 46 .
} 
had a duty to disclose. The court concluded that the notice clause was ambiguous on this point, invoked the usual canon of construing the provisions of an insurance policy in the light most favorable to the insured, and held that failure to disclose the accidental death benefits provisions of the life insurance policy was not a breach of the notice provision. The opinion stated that:

It is clear there is a real difference between a life policy with double indemnity and disability benefits and an accident and health policy, such as we have here, providing for death benefits. The dominant purpose of the two kinds of policies is entirely different, the risks which they cover overlap in only a small segment, and it would not occur to the ordinary man that one was additional insurance of the sort covered by the other. When, in addition to this, those skilled in insurance are in disagreement as to whether life insurance with double indemnity and disability features should be counted as additional health or accident insurance, language of a life and accident policy requiring disclosure of additional insurance of such character cannot be held to embrace life insurance policies with double indemnity and disability features without doing violence to the well settled rule of construction to which we have referred. 40

The court quoted with approval from a Ninth Circuit case, Mutual Reserve Life Ins. Co. $v$. Dobler, ${ }^{41}$ involving the converse issue: whether, in an application for a life insurance policy, the applicant was required to disclose an accident policy which provided death benefits. There, after discussing the "recognized distinction between life and accident insurance," 42 the court proceeded to decide the case on the basis of ambiguity in the wording of the question propounded to the applicant. ${ }^{43}$

'Id. at 47. The following stipulation had been entered into by the parties:

"There is a difference of opinion among insurance men generally as to whether disability insurance such as provided by the riders attached to the plaintiff's Equitable Life policies should be considered embraced within the meaning of the term 'accident or health insurance.' Some companies do and some companies do not count it in determining the amount of sickness or accident indemnity they will write for an applicant. Some companies ask in their application blanks specific questions as to whether the applicant has life insurance with disability benefits and the amount thereof." Ibid.

1137 Fed. 550 (9th Cir. 1905).

12 Id. at 553 .

13 "But it is not necessary to rest the decision of this branch of the case upon the recognized distinction between life and accident insurance. In any view of the case, we think that the most that can be claimed in behalf of the plaintiff in error for the questions so propounded to the applicant was that they were so worcled as to leave it uncertain whether they called for a disclosure of the accident insurance which he carried at that time. If the insurance company in its printed application 
It is submitted that both Bowles and Dobler reached sound results. In each case the insurer apparently urged a hypertechnical construction of its contract that was at variance with lay understanding. The two opinions certainly indicated that there is some doubt whether accidental death benefit provisions of life insurance policies are "accident insurance," and whether death benefit provisions of accident policies are "life insurance." It was precisely this doubt-existing in the minds of both laymen and insurance experts ${ }^{44}$-that prompted the court in each instance to construe the notice clause against the insurer. The actual holdings of Bowles and Dobler then, are that where there is ambiguity in a notice clause, a difference between life and accident insurance will be recognized in order to prevent forfeiture.

The second case relied upon by the Third Circuit to reinforce its distinction between accident and life insurance was Baumann $v$. Preferred Acc. Ins. Co. ${ }^{45}$ There, an applicant for accident insurance falsely denied that other insurers had previously refused his application for accident, health or life insurance. The outcome of the case depended upon whether this misstatement was a representation or a warranty. ${ }^{46}$ Counsel for the insured attempted to invoke a statute providing that misstatements in policies issued "by any life insurance corporation," should, in the absence of fraud, be deemed representations and not warranties. ${ }^{47}$ The court held this statute inapplicable because of the specific reference to life insurance corporations. The plaintiff's policy was issued by an accident insurance

employed ambiguous terms or words of doubtful import, it cannot complain if they were construed as they were by the applicant, or if the agent so advised him as to their meaning." Id. at 553-54.

"See note 40 supra.

4225 N.Y. 480 , 122 N.E. 628 (1919).

16 The trial court had directed a verdict for the defendant on the ground of breach of warranty. If the statement was a warranty, this action was correct: falsity is the only issue in warranty cases, and the falsity of this statement was clearly shown. If the statement was a representation, however, the insurer would not have been released from liability unless it was both false and either material to the risk assumed by the insurer or made with actual intent to deceive. N.Y. Sess. Laws 1913, ch. 155, $\S 2$ at 280 . Plaintiff contended that this was a representation, presenting a question of fact as to materiality which should have been submitted to the jury. 225 N.Y. at 484,122 N.E. at 628 .

${ }^{47}$ N.Y. Sess. Laws 1906 , ch. $326, \S 16$ provided that:

"Every policy of insurance issued or delivered within the state on or after the first day of January, nineteen hundred and seven, by any life insurance corporation doing business within the state shall contain the entire contract between the parties ... and all statements purporting to be made by the insured shall in the absence of fraud be deemed representations and not warranties. ..." 
corporation and was an "accident policy," even though it provided for indemnity in case of death resulting from bodily injury effected through accidental means. The court justified its decision on the ground that:

It seems impossible that the experienced insurance men who framed the Insurance Law failed for a moment to have in mind the distinction between life insurance and accident insurance. The law is full of provisions which distinguish between them. Even in the popular speech, life insurance and accident insurance mean entirely different things. ${ }^{48}$

It is arguable that mention of the "distinction between life insurance and accident insurance" was unnecessary in Baumann. The statute applied only to policies of insurance "issued ... by any life insurance corporation," and the defendant was not a life insurance corporation by regulatory classification. Hence, the statute was not applicable. Mere allusion to the "distinction," with no attempt to indicate its relevance to the issue before the court, served no useful purpose. In fact it served only to mislead.

The third case relied upon by the Third Circuit involved the interpretation of a partnership buy-sell agreement executed by two accountants. In Oglesby-Barnitz Bank of Trust Co. v. Clark, ${ }^{40}$ each of two partners had agreed to insure his own life in the sum of 10,000 dollars, naming the other partner as beneficiary. Upon the death of one of the partners, the proceeds of the policy on his life were to be used to purchase his interest in the partnership. It appeared that each partner had in fact taken out a 10,000 dollar life insurance policy as required by the agreement, and each had raised the limits of coverage from 10,000 to 20,000 dollars several years thereafter. In addition, each had procured accidental death policies in the amount of 10,000 dollars, designating the other as beneficiary. These policies had also been increased from 10,000 to 20,000 dollars some years later. One of the partners died, and the amount payable by the survivor for the decedent's interest was controverted. The decedent's executor claimed that the entire proceeds of both policies, 40,000 dollars, was payable under the agreement. The trial court so held. The Ohio Court of Appeals held, however, that only 10,000 dollars was due and payable to the decedent's estate under its construction of the contract. In eliminating

18225 N.Y. at 487,122 N.E. at 629.

112 Ohio App. 31, 175 N.E.2d 98 (1959). 
the proceeds of the accident policy from the survivor's liability under the contract, the appellate court stated that:

As we read the words of the contracting parties, we are of the opinion that reasonable minds could conclude only that these men of business meant that their lives should be insured against death from any cause in the amount of ten thousand dollars, and that insurance covering death from accident alone was not intended. A life is not insured, as that term is employed by ordinary men of business, if the insurance is limited to death by accident alone. ${ }^{\mathbf{5 0}}$

The court further held that the survivor could keep the additional 10,000 dollars in life insurance proceeds not required by the contract. .1

The outcome in Clark thus depended solely on the construction of a contract entered into by two "ordinary men of business." Noel, on the other hand, involved a construction of the Internal Revenue Code, which certainly was not drafted by "ordinary men of business," and required the use of a much different technique of construction.

Finally, the Third Circuit relied upon Orr v. Prudential Ins. Co. of $A$ merica,52 a case in which the insured owned a life insurance contract with an accidental death benefits "rider." This rider provided that the accidental death benefits provision should be null and void when any of the non-forfeiture provisions of the base policy became operative. ${ }^{53}$ The insured defaulted on premium payments, after which his life insurance coverage was extended by the non-forfeiture provisions of the base policy for an additional 288 days. During this extension the insured was killed in an automobile accident. The insurer admitted liability under the base policy, but denied liability

${ }^{50}$ Id. at 38,175 N.E.2d at 103 .

51 Id. at 41,175 N.E.2d at $104-05$.

82274 Mass. 212, 174 N.E. 204 (1931).

"The rider read as follows:

"In addition to the insurance under the policy to which this rider is attached, and subject to the provisions of said Policy, the Company will pay at its Home Office, as an Accidental Death Benefit,-Ten Thousand-Dollars, to the Beneficiary ... under said Policy ... immediately upon receipt of due proof [that such death occurred during the continuance of said Policy] while there was no default in the payment of premium, as a result, directly and independently of all other causes, of bodily injuries, effected solely through external, violent and accidental means . . . and that such deatls occurred within sixty days of the accident. . . . These provisions as to Accidental Death Benefits shall become null and void if any of the Non-forfeiture Provisions of said Policy shall be operative, and the Accidental Death Benefit or the extra premium hereinbefore mentioned shall not be included in determining any value or extention period under said provisions." Id. at 213-14, 174 N.E. at 204-05. 
under the accidental death benefits rider. The beneficiary contended that the nullity provision of the rider was unenforceable because it was printed in type smaller than that required by statute for policies of insurance "against loss or damage ... or death by accident of the assured. . .."54 The trial judge ruled that this statute was inapplicable because the policy in question was a life insurance policy according to legislative classification. Although agreeing with the trial court's reasoning, the Supreme Judicial Court of Massachussetts provided an alternative ground for its decision. Even assuming that the statute could be construed to apply to life policies with accidental death benefit clauses, the appellate court held that it could not be used to impose a new obligation on the insurer which would not have existed if the voidability provisions had complied with the statute. ${ }^{55}$

Upon examination it will be seen that the reasoning of the Orr case is inapplicable to Noel. The decision in Orr rests on the power of the legislature of Massachusetts to regulate insurance companies and policies according to its own scheme of classification. Its classification is not binding on the courts or legislatures of any other jurisdiction. Neither is it binding on (although it may be helpful to) the courts of Massachusetts in deciding cases that present the "life insurance-accident insurance" issue in a different context. Moreover, although the legislative classification argument seemed conclusive, the court felt it necessary to demonstrate that the result would have been the same regardless of how it had decided the classification issue. Thus, citation of the Orr case as authority for the proposition that there is a clear distinction between "life" and "accident" insurance seems unwarranted.

The examination of these four cases indicates that they do not support the distinction which the Third Circuit attempted to draw in Noel. The most that can be said for them is that for some pur. poses, and as a matter of statutory or contractual interpretation,

5 Mass. Acts 1910 , ch. $493, \S 1$ provided that:

"No policy of insurance against loss or damage from disease or by the bodily injury or death by accident of the assured shall be issued or delivered in this common. wealth .... (c) ... unless every part is plainly printed in type not smaller than long primer or ten point type ...."

EE "We think the contract of insurance was not void in respect to the part so printed, but was enforceable to the extent of the right and obligation which would be created by the insurance contract if the statute in reference to the printing were not violated." 274 Mass. at 216, 174 N.E. at 205. 
courts have sometimes recognized a distinction between accident insurance and life insurance. (Of course, the converse is also true.) ${ }^{56}$ In each case, the distinction depended upon factors not presented in Noel: ambiguous wording in the insurance contract or application, plus the familiar rule of construction in favor of the insured; construction of private agreements to effectuate the presumed intention of the parties; or construction of state regulatory statutes directed toward "life insurance corporations" or "policies of insurance against death by accident."

The crucial question raised by the Noel case is not whether, in some jurisdictions, under some circumstances, "accident insurance" is treated differently from "life insurance." The real question is whether or not the proceeds of a particular type of policy, providing for payment to a named beneficiary in case of death by accident, are includible in the gross estate of the insured as "insurance under policies on the life of the decedent," under section $2042(2)$ of the Internal Revenue Code. Discussion must proceed from the statute itself, and its predecessors.

\section{III}

\section{LIFE INSURANCE AND THE EsTATE TAX}

\section{A. Section 2042}

The Revenue Act of 1916 contained no provision explicitly taxing proceeds of life insurance. Although proceeds of insurance payable to the estate of the decedent were regarded as taxable under the act, ${ }^{57}$ the taxability of such proceeds payable to other beneficiaries was doubtful. Consequently, the Revenue Act of 1918 expressly included proceeds of life insurance in the gross estate of the insured. ${ }^{58}$ All proceeds payable to the insured's estate were in-

50 See, e.g., Geisler v. Mutual Benefit Health \& Acc. Ass'n, 159 Kan. 452, 155 P.2d 435 (1945); Provident Life \& Acc. Ins. Co. v. Rimmer, 157 Tenn. 597, 12 S.W.2d 365 (1928).

${ }^{57}$ Revenue Act of 1916 , ch. $463, \S 202$ (a), 39 Stat. 777 , taxed all property subject to payment of charges against the estate and expenses of administration, and distributable as part of the decedent's estate. The House report accompanying the Revenue Act of 1918 stated that "insurance payable to the executor or to the estate is now regarded as falling within section 202 (a) of the existing statute and this construction of the existing statute is now written into the new bill for the sake of clearness. The amendment will serve the further purpose of putting on notice those who acquaint themselves with the statute for the purpose of making more definite plans for the disposition of their property." H.R. REP. No. 767, 65th Cong., 2d Sess. 102 (1918).

${ }^{58}$ Revenue Act of 1918 , ch. 18, $\S 402(f), 40$ Stat. 1098. That section provided 
cludible; proceeds payable to other beneficiaries were includible if they exceeded 40,000 dollars and the policies had been taken out by the decedent upon his own life. This provision was re-enacted in 1924,59 and remained in effect until 1942. Its construction was the issue in the Ackerman case, ${ }^{60}$ where the insured's widow was named beneficiary of several policies payable in the event of accidental death. Although the aggregate amount of the proceeds exceeded the statutory exemption, the executor did not include them in the insured's gross estate on the ground that the statute included only proceeds of "life insurance," whereas the proceeds involved were from "accident insurance." The Board of Tax Appeals rejected the executor's contention, stating that:

It is well recognized that there is a distinction between life insurance and accident insurance, the former insuring against death in any event and the latter (where accidental death policies are involved) against death under certain contingencies, but we fail to see why one is not taken out upon the life of the policy holder as much as the other. In each case the risk assumed by the insurer is the loss of the insured's life, and the payment of the insurance money is contingent upon the loss of life.... The provisions of Section $302(\mathrm{~g})$ are broad enough to include both classes of insurance and we find nothing which would permit us, even under the general rule of resolving doubts in the construction of taxing statutes against the Government and in favor of the taxpayer, to exclude amounts received as accident insurance from its application. ${ }^{61}$

In the intervening thirty-five years before Noel, this classic statement apparently was never controverted by Congress or the judiciary.

The first, and only, Supreme Court interpretation of section 302 (g) occurred in Helvering $v$. Le Gierse. 62 There the decedent, a woman eighty years of age, had purchased a life insurance policy jointly with a lifetime annuity. No physical examination was required, and the policy would not have been issued without the

that the gross estate should include "the amount receivable by the executor as in. surance under policies taken out by the decedent upon his own life; and to the extent of the excess over $\$ 40,000$ of the amount receivable by all other beneficiaries as insurance under policies taken out by the decedent upon his own life."

s9 Revenue Act of 1924, ch. 234, $\$ 302$ (g), 43 Stat. 305.

${ }^{\circ} 15$ B.T.A. 635 (1929). See text accompanying notes $6-8,13$ supra.

${ }^{01} I d$. at 637-88. (Emphasis added.)

62 912 U.S. 531 (1941). 
annuity contract. ${ }^{63}$ Her executors contended that since the insurance proceeds were less than the 40,000 dollar statutory exemption, they were not includible in the decedent's gross estate. The Commissioner argued that the insurance-annuity combination was not "insurance," "but rather a transfer taking effect at death and thus fully taxable. ${ }^{04}$ Since section 302 (g) applied to proceeds "receivable by other beneficiaries as insurance under policies taken out by the decedent upon his own life," the outcome depended upon the Court's interpretation of the word "insurance." (This distinguishes Le Gierse from Noel, where the proceeds were admittedly insurance, but the interpretation of the phrase "on the life of the decedent" was in controversy.)

After an examination of the legislative history and administrative interpretations of section $302(\mathrm{~g})$, the Court was forced to conclude that "conventional aids to construction are of little assistance here."65. This was quite an understatement. The committee reports indicated only that section 302 (g) was intended to close a tax loophole by bringing into the gross estate the proceeds of life insurance payable to beneficiaries other than the decedent.68 The Treasury Regulations defined insurance as "life insurance of every description, including death benefits paid by fraternal beneficial societies, operating under the lodge system."67 (That definition has never been clarified and is still in effect. ${ }^{68}$ Relying primarily upon the usage of the term "insurance," the Court held that Congress intended section 302 (g) to apply only to transactions involving an

\footnotetext{
6s Id. at 537 .

- Section 302 (c) of the Revenue Act of 1926, a re-enactment of Revenue Act of 1918 , ch. $18, \S 402$ (c), 40 Stat. 1097 , taxed transfers by a decedent "in contemplation of or intended to take effect in possession or enjoyment at or after his death ...." Revenue Act of 1926, ch. 27, $\$ 302$ (c), 44 Stat. 70 .

${ }^{65} 312$ U.S. at 538.

oc "The provision with respect to specific beneficiaries has been included for the reason that insurance payable to such beneficiaries usually passes under a contract to which the insurance company and the individual beneficiary are the parties in interest and over which the executor exercises no control. Amounts passing in this way are not liable for expenses of administration or debts of the decedent and therefore do not fall within the existing provisions defining the gross estate. It has been brought to the attention of the Committee that wealthy persons have and now anticipate resorting to this method of defeating the estate tax. Agents of insurance companies have openly urged persons of wealth to take out additional insurance payable to specific beneficiaries for the reason that such insurance would not be included in the gross estate." H.R. REP. No. 767, 65th Cong., 2d Sess. 22 (1918); S. REP. No. 617, 65th Cong., 3d Sess. 42 (1918).

${ }^{\circ}$ Treas. Reg. 37, art. 32 (1919).

${ }^{68}$ See Treas. Reg. $\$ 20.2042-1$ (a) (1) (1958).
} 
actual shifting of the risk of economic loss resulting from premature death. ${ }^{69}$ Viewing the transaction as a whole, the Court found no risk-shifting in the policy-annuity transactions; the two contracts involved opposite risks, and in combination each neutralized the risk of the other. The total consideration exceeded the face amount of the policy. Interest would meet the annuity obligations as long as the policyholder lived, and at her death the principal would pay the "life insurance" obligation. Thus, the Court held that this was an investment, not insurance. As a result, the proceeds were fully taxable under section 302 (c) as a transfer taking effect at death. Two justices dissented without opinion.

Ackerman is cited twice in Le Gierse, as authority for statements that: (l) the elements of risk-shifting and risk-distributing are essential to a life insurance contract; ${ }^{70}$ and (2) it may be assumed that Congress meant to tax proceeds of a transfer possessing these features. ${ }^{71}$

It is submitted that Le Gierse is clear authority for two propositions: (l) "Insurance," as that term was used in section 302 (g), means any transaction by which the risk of loss from premature death is shifted from the decedent to the insurer; and (2) Congress intended this broad construction of section 302 (g). Since Ackerman was cited in support of the holding on both of these propositions, there can be no doubt that seven justices approved its rationale.

Although section $302(\mathrm{~g})$ appeared to be applicable only to policies taken out by the decedent upon his own life, it was never really so construed by the Treasury. Even though someone other than the insured applied for and obtained the policy, naming a person other than the decedent or his estate as beneficiary, the regulations insisted that the proceeds might nevertheless be taxed to the decedent's estate. The Treasury vacillated, however, over the test of includability: first, payment of premiums by the decedent was held sufficient; ${ }^{72}$ later, possession of incidents of ownership in the policy was required, in addition to the payment of premiums; ${ }^{73}$ still later, payment of premiums and possession of incidents of ownership were

312 .U.S. at 542.

70 Id. at 539. Note the use of the term "Iife insurance contract," even though some of the policies in Ackerman were technically accident policies.

${ }^{71}$ Id. at 540 .

${ }^{3}$ Treas. Reg. 37, art. 32 (1919).

73 Treas. Reg. 70, arts. 25, 27 (1926). 
accepted as alternative tests of includibility. ${ }^{74}$ Congress adopted this final Treasury interpretation in 1942,75 at the same time deleting the 40,000 dollar exemption for insurance proceeds payable to beneficiaries other than the insured's estate. There was no change in the definition of insurance.

In 1950, the Second Circuit thwarted an attempt to impose a narrow, technical construction on this statute in the case of Commissioner $v$. Treganowan. ${ }^{78}$ There the decedent was a member of the New York Stock Exchange, which paid 20,000 dollars to his widow because of his death. The payment came from a "gratuity fund" originally acquired through assessment of members and allocation of part of the net profits of the exchange. Each new member of the exchange was required to make an initial contribution of fifteen dollars to the fund. The fund guaranteed to pay 20,000 dollars to the widow and children of any deceased member, and each surviving member could be assessed fifteen dollars to provide this fund. ${ }^{77}$ The fund was highly solvent because of additions from net profits-so solvent, in fact, that current payments could be met out of accumulated income, and no membership assessment had been made for nine years preceding the decedent's death.

The Commissioner claimed that the payment to the decedent's widow from this fund was includible in his gross estate as insurance proceeds. The Tax Court held in favor of the estate on the ground that the gratuity fund involved no risk-shifting as required by Le Gierse. The Second Circuit disagreed, holding that the risk of premature death of a member was passed on to the group. That is, if a member died prematurely the amount paid to his survivors would be more than the total of his contributions to the fund. The plan was actually very similar to the scheme evolved by medieval guilds and later used by fraternal benefit societies. ${ }^{78}$ Thus, the court held that the fund constituted insurance under the Le Gierse test. ${ }^{79}$

\footnotetext{
74 Treas. Reg. 80, arts. 25, 27 (1937).

TE Revenue Act of 1942, ch. 619, $\S 404,56$ Stat. 944.

${ }^{70} 183$ F.2d 288 (2d Gir.), cert. denied, 340 U.S. 853 (1950), reversing 13 T.C. 159 (1949).

${ }^{77}$ With 1374 living members (as of 1950), the exchange could easily meet this obligation. Any member who failed to pay an assessment was subject to loss of his seat. 183 F.2d at 289-90.

78 BASYe, History and OpERATION OF Fraternal Insurance 11, 18-19, 22-40 (1919).

${ }^{70}$ The decedent had no power to assign his rights in the fund or designate the beneficiary. His interest in the fund (and the interests of his beneficiaries as prescribed by the constitution of the exchange) would terminate, however, if he sold
} 
The executors had argued that the fund was not "life insurance" as the term is commonly used. They also pointed out that the assessments bore no relation to the age, health or living habits of the members; no medical examination was required, and no use was made of actuarial computations or mortality tables. To this contention. Judge Clark retorted, "[T] essentials." 80 In his separate opinion, dissenting on another issue, Judge Learned Hand was even more specific, stating that:

The respondent's argument, as I understand it, is that in the tax statute the word should be limited to conventional life insurance, based upon adequate actuarial bases, and perhaps limited by the exclusion of bad risks. That appears to me must [sic] too circumscribed a reading of the phrase: 'Insurance of every description.' Back of the statute lies the purpose, I think, to include in a man's estate whatever provision he may have made for his successors, which depends on his death, and which he has secured by means of 'premiums' or 'other considerations,' paid during his life. ${ }^{82}$

The Supreme Court denied certiorari, ${ }^{83}$ and the Tax Court has followed Treganowan. ${ }^{84}$

The 1954 Code eliminated the premium payment test for insurance payable to other beneficiaries, leaving incidents of ownership as the sole test of includibility. ${ }^{85}$ Like the 1918 and 1942 acts, the 1954 Code contains no express definition of "life insurance." Section 2042 (2) employs the same phraseology as the 1942 act concerning includibility of proceeds receivable by "beneficiaries as insurance under policies on the life of the decedent."

In its consideration of the Noel case the Tax Court concluded that section 2042 (2), "although significantly different in other respects, is substantially identical [to section 302 (g) of the Revenue

his seat. This was found to be a sufficient incident of ownership to satisfy the statutory requirement. 183 F.2d at 292-93. Judge Fand dissented from this part of the opinion. Although he agreed that the fund proceeds were insurance, he did not agree that the decedent had retained incidents of ownership. Accordingly, he would have included in the gross estate only that proportion of the proceeds which was represented by premiums paid after the effective date of the 1942 amendment. $I d$. at 294.

${ }^{80} \mathrm{Id}$. at 291 (citing Estate of Keller v. Commissioner, 312 U.S. 543 (1941), a companion case to $L e$ Gierse).

81 See note 79 supra.

as 183 F.2d at 293. In his discussion of the phrase "insurance of every description," Judge Hand evidently confused the regulations with the statutory terminology.

${ }^{83}$ See note 76 supra.

st Estate of Wilham E. Edmonds, 16 T.C. 110, 117 (1951).

${ }^{85}$ See note 5 supra. 
Act of 1924] ... in relation to the question whether the accident policies constitute 'insurance . . . on the life of the decedent.' "88 The Third Circuit apparently agreed, since it made no attempt to distinguish the Ackerman case on the basis of the 1942 amendment.

The Third Circuit did not mention Le Gierse or Treganowan in its opinion. This was a shocking oversight, since these are apparently the only two appellate opinions that have directly considered the ambit of section 2042 (2) and its predecessors. Moreover, Ackerman was dismissed by the court of appeals with the remark that the construction of the statute was erroneous in that case, as was the Tax Court's construction in Noel.87 Similarly, the Treasury's definition of insurance-unchanged since 1918 and subjected to a broad, non-technical construction in Ackerman, Le Gierse and Treganowan with the silent acquiescence of Congress-was discarded with the comment, "We find this definition of little assistance in the instant case." 88 The opinion then proceeded to a discussion of the "ordinary, plain and generally accepted meaning" of section 2042 (2), under which it arrived at the "distinction" discussed earlier.

Where the meaning of a statute is doubtful, deference should be accorded to the interpretation given the provision by the agency charged with its administration. ${ }^{89}$ The reason for this is that if "such construction does not properly interpret the meaning and intent of Congress, [then Congress] . . . can readily correct the same." ${ }^{\text {"9o }}$ Congressional re-enactment of the statute without change justifies the inference that the administrative interpretation is correct. In fact, the Supreme Court has held that "the re-enactment by Congress, without change, of a statute, which had previously received long continued executive construction, is an adoption by Congress of such construction." 91 Although the Court has not adhered to this rule when it felt the administrative determination clearly erroneous, ${ }^{92}$ it does not lightly disregard the coordinate

\footnotetext{
${ }^{80} 39$ T.C. at 470 .

87332 F.2d at 952 .

${ }^{88} I d$. at 951 .

${ }^{80}$ United States v. Healey, 160 U.S. 136 (1895); Robertson v. Downing, 127 U.S. 607 (1888).

פo Mayes v. Paul Jones \& Co., 270 Fed. 121, 130 (6th Cir. 1921).

${ }^{01}$ United States v. Hermanos, 209 U.S. 337, 339 (1908). See Helvering v. Winmill, 305 U.S. 79, 82 (1938); National Lead Co. v. United States, 252 U.S. 140, 145 (1920); United States v. Falk, 204 U.S. 143, 152 (1907).

${ }^{2}$ Biddle v. Commissioner, 302 U.S. 573582 (1938); Koshland v. Helvering, 298 U.S. 441, 445 (1936).
} 
judgment of the other two governmental branches in matters of statutory construction. The deference accorded administrative regulations may result in a "trite and distinctly unrealistic canon of construction," 93 but this risk is not unreasonable when contrasted with the dangers inherent in judicial disregard of settled, legislatively-accepted interpretations. In the Noel case, observance of the usual rules of construction would have led to a more equitable result. ${ }^{94}$

The Third Circuit's final departure from the pre-existing administrative and judicial interpretations of section 2042 (2) was its assertion that the inclusion of air travel insurance proceeds in the decedent's gross estate would "lead to an unreasonable result at variance with the intent of Congress and the manifest purpose of the statute as a whole." 95 Corroboration for this amazing statement was found in the legislative history of section 2042 and its predecesssors, from which the court concluded that "the purpose of [section 2042 (2)] . . . , like that of its earliest predecessor, is to foreclose resort to the purchase of .life insurance as a means of tax avoidance." 98

The court evidently assumed that accidental death benefit policies will not be purchased for purposes of tax avoidance. This assumption is open to serious question. It is well known that tax planning, particularly the minimizing of death taxes, is an integral part of estate planning. The knowledge that proceeds of such insurance can be passed on to beneficiaries other than the insured without being included in the decedent's gross estate may well induce executives whose work requires considerable air travel to purchase large amounts of this type of insurance. Furthermore, if the Noel rationale is extended to proceeds of other types of accident insurance, ${ }^{97}$ as well as to proceeds of death benefit provisions in ordinary life insurance policies, their exemption from the estate tax will

98 Paul, Life Insurance and the Federal Estate Tax, 52 HARv. L. REv. 1037, 1049 (1939).

* See discussion of equities p. 55 infra.

os 332 F.2d at 954 .

${ }^{\circ}$ Ibid. See text accompanying note 66 supra.

or Curiously, Noel's executors included in his gross estate the proceeds of an "aviation accident policy" issued by The Maryland Casualty Company. It was described as a term rather than a trip policy. Brief for Petitioners-Appellants, p. 27a. When questioned by the trial judge as to how this term policy differed from the policies in litigation, the attorney for the estate answered that "probably the same principal [sic] sbould apply." Brief for Petitioners-Appellants, p. 29a. 
offer a substantial inducement for additional purchases of such polcies. $^{98}$ Although uncertainty exists regarding the amount by which insurance purchases may increase as a result of Noel and its possible progeny, the Third Circuit's tacit assumption that no such increase will occur seems almost reckless.

\section{B. Other Sections}

Even if the Third Circuit had been correct in its conclusion of non-includibility under section 2042, this would not have been determinative of the litigation in favor of the estate. It is recognized that the provisions of section 2042 (2) are not exclusive; proceeds of flight insurance may well be taxable under other provisions of the Code. ${ }^{98}$ Nevertheless, the court apparently proceeded upon the assumption that taxation of the proceeds of Noel's flight insurance under the federal estate tax could be effected only under section 2042.

The opinion acknowledged the fact that Noel possessed exercisable incidents of ownership in the policy at the time of his death, ${ }^{100}$ and section 2033 expressly includes in the gross estate all property owned by the decedent at his death. 101 Since the policy was owned by the insured and the proceeds were transferred by reason of his death, a discussion of taxability under section 2033 would seem to have been mandatory. ${ }^{102}$

Moreover, Noel retained the right to assign or surrender the

\footnotetext{
${ }^{\circ 8}$ Cf. 21 J. TAxation 163, 164 (1964):

"In cases of death due to accident, the insurance proceeds would be includable in the victim's estate if they were paid under a life policy. However, if lie had been tax conscious enough to have his life policy written so as to exclude accidental death (assuming this could be done) and to have taken a separate accident policy for such an eventuality, the proceeds would be tax-free. This could be a significant tax difference, especially since many life policies provide double indemnity for accidental death. Since the Third Circuit's theory does not provide for an allocation but prescribes a dominant purpose classification of insurance, this technique is more than just academic. Insurance companies themselves would take interest in this strange result, with an eye toward changing policy forms."

Do See Lowndes \& Kramer, Feperal Estate and Gift Taxes 286-87 (2d ed. 1962).

100 "Each policy reserved to the insured the rigbt to assign it or to change the beneficiary thereof without the consent of the beneficiary originally designated. "These were exercisable incidents of ownership within the meaning of the statute." 332 F.2d at 951 .

101 INT. REv. ConE of 1954, § 2033 provides that:

"The value of the gross estate shall include the value of all property to the extent of the interest therein of the decedent at the time of his death."

102 Presumably, the policies would be valued for this purpose according to their face amount, Goodman v. Granger, 243 F.2d 264 (3d Cir.), cert. denied, 355 U.S. 835 (1957).
} 
policies, and to change the beneficiary. These rights were exercisable by the decedent alone, and were in existence at the time of his death. The beneficial interest of his wife arising out of his contracts with the insurers was subject to these retained powers. Thus, it is possible that the insurance proceeds could have been taxed to Noel's estate under section $2038^{103}$ as a transfer subject to a power to alter, amend, terminate or revoke.

Even if the court had found that Noel effected a valid assignment of the policies to his wife ${ }^{104}$ and retained no incidents of ownership, the estate would not necessarily have escaped taxation. The proceeds might have been included in Noel's estate as property transferred in contemplation of death under section 2035.105 The estate would have been compelled to overcome a presumption in favor of includibility by demonstrating a lifetime motive for the transfer-a most difficult, if not impossible, task in this case.

A great deal more could be said about taxing flight insurance proceeds under provisions of the estate tax other than section 2042. It is the writer's thesis, however, that such proceeds are clearly taxable under section 2042 without reference to other provisions. This limited discussion has been inserted merely to indicate why

${ }^{108}$ INT. REV. CODE OF 1954, § 2038 provides in part as follows: “SEC. 2038. REVOCABLE TRANSFERS.

"(a) IN GENERAL-The value of the gross estate shall include the value of all property-

“(1) Transfers AFter JUNE 22, 1936.-To the extent of any interest therein of which the decedent has at any time made a transfer (except in case of a bona fide sale for an adequate and full consideration in money or moncy's worth), by trust or otherwise, where the enjoyment thereof was subject at the date of his death to any change through the exercise of a power (in whatever capacity exercisable) by the decedent alone or by the decedent in conjunction with any other person (without regard to when or from what source the decedent acquired such power), to alter, amend, revoke, or terminate, or where any such power is relinquished in contemplation of decedent's death."

But see Estate of Harper, 11 T.C. 717 (1948).

104 See text accompanying note 11 supra.

${ }_{205}$ INT. REV. CODE of 1954, $\$ 2035$ provides in part as follows: "SEC. 2035. TRANSACTIONS IN CONTEMPLATION OF DEATH.

“ (a) GenERAL RuLE.-The value of the gross estate shall include the value of all property to the extent of any interest therein of which the decedent has at any time made a transfer (except in case of a bona fide sale for an adequate and full con. sideration in money or money's worth), by trust or otherwise, in contemplation of his death."

There has been some question whether $\$ 2035$ taxes only gifts in contemplation of certain death, to the exclusion of death by fortuitous external causes. There seems to be no sound reason for such a distinction, however. See LowndEs \& Kramer, op. cit. supra note 99 , at 70 . 
the Third Circuit, having rejected the application of section 2042, should have considered the applicability of these other provisions.

\section{Equities}

Apparently, the Third Circuit's excursion into the niceties of insurance law proved so absorbing as to obscure a very obvious, but critically important, reality: the estate tax is a revenue measure. The provision under consideration in Noel was enacted for the express purpose of enlarging the estate tax base by the inclusion of substantial assets created at the insured's death and transferred to a beneficiary of his own designation. In light of the equity of the statute there is no reason to distinguish between proceeds of flight insurance and those of life insurance. Both types of insurance involve the gratuitous transmission of wealth from a decedent to a recipient of his choice; the recipient's ability to pay the tax out of his proceeds ${ }^{106}$ does not vary according to the nature of the policy; in both cases the beneficiary receives something of a windfall, perhaps even more so in the case of flight insurance. If the proceeds of insurance that a decedent has maintained over a period of years at a substantial cost are taxed, it seems most inequitable to exempt a recovery of 125,000 dollars on an investment of only five dollars. Since the nature of the transfer and the ability of the recipient to pay the tax are identical, it seems entirely reasonable and fair to impose the same tax. Viewed in this light, the Third Circuit's discrimination in favor of flight insurance proceeds appears grossly inequitable.

IV.

\section{Income Tax Considerations}

Finally, the Third Circuit's opinion in Noel may create uncertainty as to the exclusion of accident insurance proceeds from the income tax. Correlative to its broad view of section 2042 (2) is the Treasury's interpretation of the clause exempting life insurance proceeds from the income tax. Code section 101 (a) requires the exclusion from gross income of "amounts received ... under a life insurance contract, if such amounts are paid by reason of the death

\footnotetext{
100 The beneficiary of insurance proceeds is liable for the payment of that portion of the estate tax incurred because of their inclusion in the decedent's estate. INr. REv. CODE OF 1954, $§ 2206$.
} 
of the insured."107 This phraseology is more specific than the reference in section 2042 (2) to "policies on the life of the decedent." Nevertheless, the Treasury's broad interpretation of section 2042 (2) regarding includibility of life insurance proceeds in the insured's gross estate suggests an equivalent interpretation of section 101 (a), so that the beneficiary's exemption from the income tax is coextensive with the insured's estate tax liability. The Treasury has broadly interpreted section 101 (a) to the effect that:

Death benefit payments having the characteristics of life insurance proceeds payable by reason of death under contracts, such as workmen's compensation insurance contracts, endowment contracts, or accident and health insurance contracts, are covered by this provision. ${ }^{108}$

If the Third Circuit decision becomes a precedent the Treasury may justifiably contend that the proceeds of such policies as those involved in Noel are not "life insurance" for purposes of the section 101 (a) exclusion.

Should the Treasury take such a view, one countervailing argument would be that even though no longer within the exclusion provided by section 101 (a), "accident insurance" proceeds are gifts within the purview of the exclusion afforded by section 102 (a). ${ }^{100}$ That is, it could be argued that the decedent has made a gift to the beneficiary of his claim against the insurer. The transfer of the proceeds by the insurer to the beneficiary would, of course, not be a gift, but the discharge of a contractual obligation. Thus, the beneficiary may well take the insured's basis ${ }^{110}$ and realize ordinary income to the extent that the proceeds exceed this basis. ${ }^{111}$ Applying this reasoning in the Noel case, for example, the beneficiary would have received ordinary taxable income in the amount of 124,995 dollars. ${ }^{112}$

Another strong countervailing argument would be that flight insurance proceeds are excludable under section $104(\mathrm{a})(3)$ as "amounts received through accident or health insurance for personal

\footnotetext{
${ }^{107}$ INT. REV. CODE OF 1954, \& 101 (a).

${ }^{109}$ Treas. Reg. $\$ 1.101-1$ (a) (1957). (Emphasis added.)

${ }^{108}$ INT. REv. CODE OF 1954, § 102 (a) provides that:

"Gross income does not include the value of property acquired by gift, bequest, devise, or inheritance."

${ }^{220}$ See INT. REv. CODE OF 1954, § 1015 (a).

${ }^{111}$ See Cooper v. Commissioner, 197 F.2d 951 (4th Cir. 1952); Hatch v. Commission. er, 190 F.2d 254 (2d Cir. 1951); Helvering v. Roth, 115 F.2d 239 (2d Cir. 1940).

212 The amount of the proceeds less the $\$ 5$ basis of the policies in the hands of the decedent.
} 
injuries or sickness ...."113 This provision originated with the Revenue Act of 1918, as section 213 (b) (6)..$^{114}$ It became section 22 (b) (5) of the Revenue Act of 1928, and retained this designation in the 1939 Code.

The provision is susceptible of a restrictive interpretation that would limit the exclusion to proceeds of accident insurance received by the insured himself. The Treasury, however, did not originally contend that the exclusion was personal to the insured; from the very first, its regulations accorded a wide ambit to the exclusion:

Whether he be alive or dead, the amounts received by an insured or his estate or other beneficiaries through accident or health insurance or under workmen's compensation acts as compensation for personal injuries or sickness are excluded from the gross income of the insured, his estate and other beneficiaries. ${ }^{115}$

This interpretation remained in effect for over fifteen years. In the regulations for the 1934 act, however, reference to section 22 (b) (5) was eliminated.110 The reason for this deletion is unclear, but apparently it reflected a change in Treasury policy. This conclusion is strengthened by the fact that the Commissioner took the position, in cases arising under the 1934 and 1936 acts, ${ }^{117}$ that the accident and health insurance exclusion was personal to the insured.

This contention was advanced by the Commissioner to the Board of Tax Appeals in Castner Garage, Ltd..$^{118}$ In that case, four closely-

11s INT. REv. CODE OF 1954, $\$ 104$ (a) provides in part as follows: "SEC. 104. COMPENSATION FOR INJURIES OR SICKNESS.

"(a) IN General.-Except in the case of amounts attributable to (and not in excess of) deductions allowed under section 213 (relating to medical, etc., expenses) for any prior taxable year, gross income does not include-

"(3) amounts received through accident or health insurance for personal injuries or sickness (other than amounts received by an employee, to the extent such amounts (A) are attributable to contributions by the employer which were not includible in the gross income of the employee, or (B) are paid by the employer) . . .."

${ }_{114}$ Revenue Act of 1918 , ch. 18, $\$ 213$ (b) (6), 40 Stat. 1065, provided in part as follows:

"Sec, 213. That for the purposes of this title ... the term 'gross income'-

"(b) Does not include the following items . . .

“(6) Amounts received, through accident or health insurance or under workmen's compensation acts, as compensation for personal injuries or sickness, plus the amount of any damages received whether by suit or agreement on account of such injuries or sickness."

118 Treas, Reg. 45, art. 72 (1919).

${ }^{110}$ See Treas. Reg. 86 (1935).

${ }^{117}$ Cases cited in notes 118,123 infra.

11843 B.T.A, 1 (1940). 
held corporations had purchased combined life, health and accident policies covering their president, who was also their majority stockholder. The insured subsequently became disabled, and each corporation received disability payments from the insurer. The Commissioner contended that the payments were not excludable under section 22 (b) (5), but were ordinary income to the corporations. He argued that the exclusion applied only to individuals, and that Congress intended for it to be personal to the insured. The Board apparently found no clue in the statute itself, for it chose to rest its decision on the Treasury regulations in existence prior to the 1934 act. ${ }^{119}$ On the strength of these regulations ${ }^{120}$ the Board concluded that "the exemption is not limited to the person who suffers the personal injuries or sickness." 121 Surprisingly, the Treasury soon acquiesced in this decision. ${ }^{122}$

The rule of the Castner Garage case was limited by the Tax Court in People's Finance \& Thrift Co. ${ }^{123}$ In that case a debtor assigued three life insurance policies to a creditor as collateral security for the payment of his obligation. The debtor was the insured and his estate the beneficiary under each policy. Two of the policies provided for disability benefits. When the debtor defaulted on his payments, the creditor offered the policies for sale at public auction, becoming the purchaser at that sale. The insured later became disabled, entitling the creditor to receive the disability payments.

The court held that since the payments were the result of a commercial investment transaction, the creditor was not entitled to an exclusion under section 22 (b) (5). The opinion went on to state that:

[W] think that the intent of the statute to limit the exemption to beneficiaries of insurance policies, as such, is apparent and that it would serve no purpose of the statute to extend the exemption to purchasers for value. The intention of the statute is clearly expressed on its face to apply the exclusion granted only to beneficiaries who suffer an otherwise uncompensated loss as the direct

${ }^{119}$ See regulation quoted in text accompanying note 115 supra.

220 "The Commissioner contends that the provision [section $22(\mathrm{~b})(5)$ ] is limited in its application to amounts received by the insured, but that argument is contrary to his own regulations and, apparently, his practice. The regulations have held consistently that the exemption was not limited to amounts received by the insured." 43 B.T.A. at 4.

121 Ibid.

122 1941-1 CUM. BULL. 2.

${ }^{128} 12$ T.C. 1052 (1949), aff'd, 184 F.2d 836 (5th Cir. 1950). 
result of the sickness or injury of an insured in whom they have an insurable interest. ${ }^{124}$

In a concurring opinion, Judge Disney stated that the payments received by the creditor were not "compensation for personal injuries or sickness," as required by the statute, but rather constituted compensation for an unpaid indebtedness. His interpretation of the congressional intent underlying section 22 (b) (5) was as follows:

In my opinion, Congress clearly, by the addition of the clause as to compensation for personal injuries or sickness, intended to prevent mere receipt of money through accident or health insurance, or under workmen's compensation acts, from being excluded from gross income of anyone receiving it, and equally clearly intended personal injury or sickness to mean bodily or mental injury to the person insured or covered by workmen's compensation acts, and did not extend the benefit of exclusion to any assignee or mere holder of insurable interest. ${ }^{125}$

Judges Murdock and Opper agreed with Judge Disney. Apparently they would have limited the exclusion to proceeds received by the insured himself, whereas the majority felt that all beneficiaries of accident and health policies were entitled to an exclusion under section 22 (b) (5).

The accident and health insurance exclusion was re-enacted as section 104 of the 1954 Code, with an additional parenthetical clause denying the exclusion for amounts received by an employee but attributable to contributions by his employer which were not included in his gross income. ${ }^{128}$ The committee reports indicate that this was the only substantial departure from prior law intended. The House report stated that:

With respect to all other amounts [i.e., amounts not received by an employee as a result of proscribed employer contributions], section 104 of this bill will apply in the same manner as section 22 (b) (5) of the 1939 Code. Thus, any amount received as workmen's compensation under a workman's compensation act will continue to be excludable from gross income under section 104, as will any amount received by a taxpayer under a policy of accident or health insurance purchased by him. ${ }^{127}$

\footnotetext{
2312 T.C. at 1055.

${ }^{295}$ Id. at 1057.

130 INT. REv. CODE OF 1954, § 104 (a) (3).

${ }^{197}$ H.R. ReP. No. 1337, 83rd Cong., 2d Sess. A32 (1954).
} 
The Senate report, after discussing the exception for employer contributions not attributed to employees, stated that:

It [section 104] will continue to exclude from gross income (in the same manner as section 22 (b) (5) of the 1939 Code) any amount received as workmen's compensation under a workmen's compensation act, as well as any amount received by a taxpayer under a policy of accident or health insurance purchased by him. ${ }^{128}$

The regulations promulgated with respect to section 104 (a) (3) follow the same pattern as the committee reports. The primary emphasis is on the treatment of proceeds paid to employees from funds or insurance arising out of their employment. The only reference to health or accident insurance purchased by individuals is the following:

If, therefore, an individual purchases a policy of accident or health insurance out of his own funds, amounts received thereunder for personal injuries or sickness are excludable from his gross income under section 104 (a) (3). See, however, section 218 and the regulations thereunder as to the inclusion in gross income of amounts attributable to deductions allowed under section 213 for any prior taxable year. ${ }^{220}$

The regulations and committee reports thus raise two questions: (1) Must the coverage be on the individual who purchases it, or may a policyholder obtain an exclusion for proceeds of any policy he may purchase covering another person in whose life and health he has an insurable interest? (2) Is the exclusion available only to the purchaser-owner of the policy, or may it be utilized by a beneficiary who is not the purchaser of the policy? The more restrictive interpretation can be argued in view of the reference in the regulations to purchases by the individual out of his own funds. But Castner Garage and People's Finance \& Thrift Co. indicate that the broader interpretation was given to section 22 (b) (5)-and section 104 (a) (3) was not, according to the committee reports, intended to

\footnotetext{
${ }^{273}$ S. REP. No 1622, 83d Cong., 2d Sess. 183 (1954).

${ }^{130}$ Treas. Reg. $\$ 1.104-1$ (d) (1956). The exclusion is limited to amounts in excess of premiums paid and deducted under $\S 213$ in the year the illness or disability occurred. The Treasury contends that premiums for accident and disability insurance are not deductible under section 213 except to the extent that they provide indemnity for hospital and medical expenses. Rev. Rul. 331, 1955-1 CuM. BuLx. 271. The Third Gircuit has ruled, contrary to the Treasury position, that premiums paid for health and accident policies are deductible in their entirety. Heard v. Commissioner, 269 F.2d 911 (3d Cir. 1959). The Commissioner has not acquiesced, but the Tax Court follows the Heard case. Compare Rev. Rul. 393, 1959-2 Cum. Burc. 457 with J. D. Edwards, 39 T.C. 78 (1962) and D. G. Kilgore, 38 T.C. 340 (1962).
} 
change the law in this respect. Accordingly, the conclusion seems inescapable that section 104 continues the section 22 (b) (5) exclusion for "beneficiaries who suffer an otherwise uncompensated loss as the direct result of the sickness or injury of an insured in whom they have an insurable interest."130

It thus appears to be immaterial whether flight insurance is termed "life insurance" or "accident insurance" for income tax purposes. If the former designation is applied, the beneficiary is entitled to an income tax exclusion under section 101 (a). If the latter characterization is employed, then apparently the exclusion is afforded by section 104 (a) (3). ${ }^{131}$

\section{V}

\section{CONCLUSION}

It has been the primary purpose of this article to show that there is no justification for allowing an estate tax exemption for flight insurance proceeds-or any other form of accidental death beneflts. While the distinction between "accident insurance" and "life insurance" may be significant in other contexts, it is meaningless in light of the history and long-standing interpretation (both administrative and judicial) of section 2042 (2) and its predecessors. That Congress intended no narrow, technical construction of section 2042 is indicated by its acquiescence in this broad interpretation for over thirtyfive years.

A second objective has been to establish that proceeds of flight insurance are excludable from gross income under the income tax.

It is hoped that the foregoing analysis has adequately demonstrated the unsoundness of the Third Circuit's opinion in Noel and contributed to the rehabilitation of Ackerman.

\footnotetext{
28012 T.C. at 1055.

232 Contra, Pyle, Accident and Sickness Insurance Under Sections 104, 105, 106 and 213 of the 1954 Internal Revenue Code, 1956 INS. L.J. 5I, 59; 34 TAXEs 363, 371 (1956):

"In my opinion, Sections 104-106 do not cover accidental death benefits in life insurance, endowment or accident and health contracts, the benefits in those sections being solely those received for "personal injuries or sickness." "
} 